\title{
New fault system to add to Los Angeles earthquake fears
}

\section{San Francisco}

THE earthquake that rocked Los Angeles last month has revealed buried faults running under the city, raising the spectre of potential disaster should more dramatic movements along the fault line occur.

Although the presence of such faults had been hypothesized, the first hard evidence came when data analysis showed that the earthquake on 1 October occurred on a previously unknown fault, rather than the Whittier fault as was first thought. This discovery will require a reevaluation of earthquake risk for the area.

Seismologists and geologists analysing the October earthquake originally placed it at the northernmost end of the Whittier fault (see Nature 329, 479; 1987). Like the San Andreas, the Whittier is a strike-slip fault - a crack along which two plates are slipping past each other. But further analysis of the seismic readings showed that the jolt on 1 October came from an east-west thrust fault - a fault along which one plate is slipping under the other. In this case, the block to the north of the fault was forced up and over the southern block, raising the overlying surface by 2 inches.

Kate Hutton, a seismologist at the California Institute of Technology, said that the major aftershock came from a compensatory slippage along a north-south fault lying next to the newly discovered thrust fault. A good candidate for the site of this movement is the northernmost tip of the Whittier fault.

Consulting geologist Thom Davis has been studying the Los Angeles basin for the past year, on contract for the US Geological Survey. Based on his observations of surface hills and folds, he predicted a system of buried thrust faults extending under Los Angeles and out to the coast. October's earthquake suggests he may be right.

Davis said that the faults are an extension to the south of a known thrust faul system that created the Santa Monica mountains, to the north of Los Angeles. That extension is significant, because it underlies the city of Los Angeles.

To assess the risk of a major earthquake from this fault system, Davis said several types of measurements are needed, including an analysis of the speed of the shortening driving the thrust, and a review of seismic data to see how much of that shortening has been relieved by earthquakes. Some relief may also be derived from 'seismic creep', a steady slippage that builds up no strain.

But if seismic creep and small earthquakes do not add up to enough relief for the measured shortening, the fault system could imply a large earthquake waiting to happen

Data analysis for the 1 October earthquake has not only changed its origin, but demoted it from a magnitude of 6.1 to 5.9 , a 58 per cent reduction in the amount of energy released, said Hutton.

The original 6.1 figure was an estimate based on reports from only a few stations. The aftershock was also downgraded, from 5.5 to 5.3 .

Hutton said that the October earthquake, which crumbled a number of old concrete buildings in Whittier, provides little prediction of what kind of damage to expect from a large earthquake, but will be useful in designing buildings better able to resist the medium-sized tremors that occasionally rock the Los Angeles area. Marcia Barinaga

\section{Geological basis of the Los Angeles fault system}

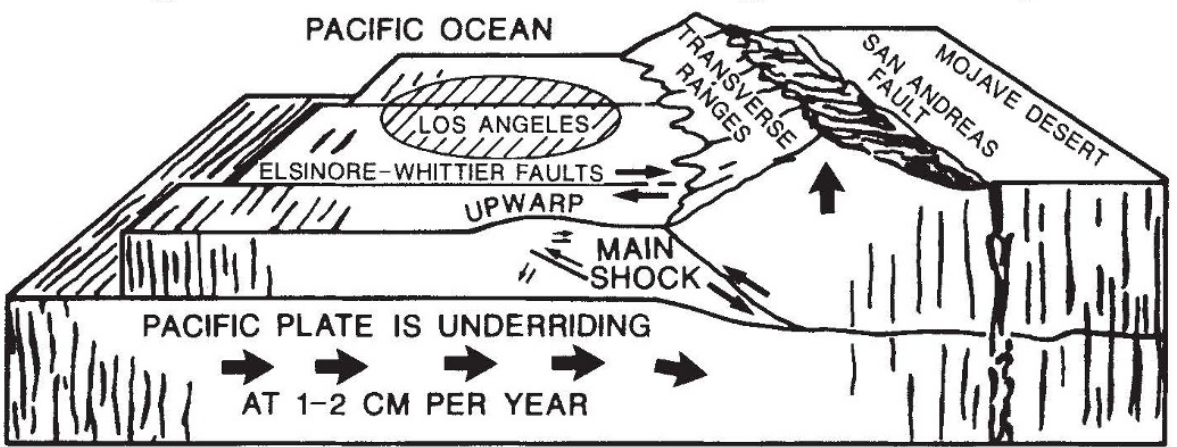

Large earthquakes may hit Los Angeles when blocks of crust slip past one another at the San Andreas and Elsinore-Whittier faults. But, as the recent earthquake shows, trouble can also come when the underlying motion of the Pacific plate causes the crust above to shorten and crumple. Data on underlying folds produced by plate movement are now being sought from oil companies, which have had an interest in them for the oil they may contain. In the long run, moderate-sized earthquakes at faults that accommodate shortening may cause more damage than the occasional big earthquake from the San Andreas and Elsinore-Whittier faults. (Figure: Bob Wallace, USGS.)
DNA fingerprint ruling

A MAN has been convicted in a British court this week on the strength of evidence from the 'genetic fingerprint' method pioneered by Dr Alec Jeffreys at Leicester University and published in Nature $(317,818 ; 1985)$.

Robert Melias was sentenced to 8 years imprisonment for a rape committed in January this year. Bristol Crown Court heard that the match of his DNA profile to that of DNA samples taken from the victim indicates odds of 4,000,000 to one against his being innocent. The conviction has been interpreted by the Home Office as a significant advance in solving crime. In another recent case the test was used to clear a man accused of murder and forensic scientists are now cooperating with police on more than 50 cases involving the fingerprint method. Demand for the fingerprinting kits, produced by ICI subsidiary Cellmark Diagnostics at a price of $£ 120.75$, is expected to increase rapidly now that police forces have seen the potential of the method realized.

S.J.H.

\section{Ariane flight delay}

FLIGHT 21 of Europe's Ariane 3 commercial rocket, scheduled for 30 December, has been put back by 5 or 6 weeks. Arianespace, the company responsible for Ariane launches, refused to accept delivery of the rocket's third-stage liquid hydrogenoxygen motor from Societé Européene de Propulsion (SEP), following concern at performance of the turbopump. Overheating of the pump caused the abortion of flight 18 in May 1986. Flight 20, scheduled for 18 November, will still go ahead. P.C.

\section{AIDS virus cultured}

Human immunodeficiency virus (HIV) has been isolated for the first time from patients in India with AIDS. Dr Pradeep Seth, a microbiologist at the All India Institute of Medical Sciences in New Delhi says it is not possible to say at present whether the virus is HIV-1, HIV-2, or a new strain.

The virus was isolated from the lymphocytes of three asymptomatic prostitutes by co-cultivation with phytohaemagglutininstimulated normal human lymphocytes. The presence of the virus was confirmed by indirect immunofluorescence using mouse monoclonal antibodies against HIV antigens p 24 and p17, and by a reverse transcriptase assay with the culture supernatants.

Because of a lack of virus typing and containment facilities, the Indian isolates have not been further characterized. "Until this is done we are not sure if it is one of the known viruses or a new strain of HIV", says Seth. Typing and characterization of Indian HIV has acquired a new urgency in the light of the peculiar HIV-antibody distribution in the country. Although there are 145 known cases of positive antibody infection, only one full-blown AIDS case has surfaced. 